\title{
Marx's Construction Method of Political Economy and the Innovative Development of Socialist Political Economy with Chinese Characteristics
}

\author{
Xiuli Cui, PhD \\ School of Economics \\ Central University of Finance and Economics \\ 39 XueYuan South Road \\ HaiDian District, Beijing, China
}

\begin{abstract}
Theory is the product of history, which has completely different forms and contents in different times. The 70-year construction of socialism with Chinese characteristics has made remarkable achievements in economic development. Past economic theories are no longer able to explain China's unique economic development model, so it is urgent to accelerate the construction of the theoretical system of socialist political economy with Chinese characteristics to adapt to the socialist economic construction with Chinese characteristics in the new era. This paper holds that Marx's theory of political economy is critical and revolutionary, but Marx's political economy construction method is constructive. Using Marx's political economy construction method to build the new political economy system of socialism with Chinese characteristics, we should take China's national subjectivity as the logical starting point, take China standing up, getting rich and getting strong as the center, and take the status quo of world development as the basic background. On the basis of digging out new materials and discovering new problems in the practice of China's 70 years of development, we should take the characteristics and development path of the "three laws" in China as the main part, deepen the theoretical analysis and logical academic construction of the "Chinese model" of economic construction, refine a new theory of academic rationality, summarize new practices with regularity, embody Chinese characteristics, Chinese style, Chinese temperament, and embody inheritance and nationality, originality and time, systematic characteristic and specialization.
\end{abstract}

Keywords: Marx: political economy, construction method, socialist political economy with Chinese characteristics

The founding of the People's Republic of China for 70 years, China's socialist practice exploration has been a great success. At the same time, the productivity has developed greatly. China has opened up the road of socialism with Chinese characteristics, revealing the huge system of advantage and vitality. The past economic theories have been unable to explain China's unique development path and mode, so it is necessary to accelerate the construction of the theoretical system of political economy with Chinese characteristics to explain China and enlighten the world, which has become a Time topic that Chinese economist must face. The construction method of Marx's political economy is the living soul of Marx's political economy, and it is a set of academic research paradigm about how to put forward, analyze and solve problems.

\section{The construction method is an integral part of Marx's political economy theory system}

The theoretical content and construction method of Marx's political economy jointly established the establishment of Marx's political economy. Only talking about Marx's political economy theory, without talking about its construction method, we cannot really know and understand Marx's political economy. The research results of political economy represented by "Das Kapital" are the carriers of Marx's method of building construction of political economics. the method of building political economics is an important part of the theory system of Marxist political economics and academic research paradigm, is to keep the Marxist political economics to keep pace with The Times, strong driving force and source of vitality.

\subsection{The political economy founded by Marx is of great significance to the world}

Marx's research on political economy can be traced back to the 1840s when he was the editor of Rheinische ZeiTung. Since then, he has devoted his life energy to the study of political economy and made remarkable achievements in the field of political economy. Marx's political and economic theories and thoughts have been fully interpreted and reflected in the Communist Manifesto, Das Kapital, Critique of Political Economy (volume 1), Manuscripts of Economic Philosophy:1844, Hired Labor and Capital, Economic Manuscripts:1857-1858 and Economic Manuscripts:1861-1863. 
While criticizing the capitalist economic theory, Marx analyzed the production process of capitalism, expounded his political economy theory dialectically and systematically, and createda unique Marxist political economy. Marx initiated the theory of surplus value, believing that surplus value is "the part of the total value of goods that reflects the surplus or unpaid labor of workers", [i] "Although only part of the labor of the worker is paid and the other part is unpaid, and the unpaid or surplus labor is the basis for the production of surplus value or profit, it seems that all labor is paid labor." ${ }^{[i i]}$ Marx takes commodities as the starting point of analyzing capitalism, and discusses the use value and value (exchange value) of commodities as well as the difference and connection between money, capital and wealth. At the same time, Marx innovatively puts forward the theory of labor duality, that is, labor can be divided into concrete labor and abstract labor. According to Marx, the value of a commodity is determined by the amount of socially necessary labor (socially necessary time) it consumes to produce it, the use value is produced by specific labor, and the value (exchange value) is produced by abstract labor. Marx also expounded that the productive forces determine the relations of production, the economic foundation determines the superstructure, the social existence determines the social consciousness and its logical and dialectical relations, and points out the limitations of the bourgeois political economy. Marx emphasized that social relations of production must adapt to the development of productive forces and the basic role of productive forces in the replacement of old and new relations of production. This is of great significance in the academic history.

\subsection{Marx's political economy theory and construction method are inseparable}

In July 1865, Marx wrote in a letter to Engels: "No matter what shortcomings in my work, they have a strength, that is, they are an artistic whole; but to achieve this, only use my method." [iii] This shows that Marx fully affirmed the importance of the method he used. Marx warned people not to understand and evaluate his works in isolation, but to combine his methods and works closely and treat them as a whole. The implication is that Marx cannot obtain his theoretical research results without using his methods. Chairman Mao once said, "The object of political economics research is mainly production relations, but political economy and historical materialism are difficult to scorers. ... Research questions should start with historical analysis." ${ }^{\text {[iv] }}$

In recent years, many domestic scholars have also made new discussions on the relationship between Marx's political economy theory and construction method. Zhang Xiong (2015) believes that Marx is the most influential figure in the criticism of political economy in the 19th century. Marx has contributed a huge spiritual legacy to us in the field of political economy criticism. Marx's political economy criticism is a historical theory and a philosophical dialectic. Wei Xinghua (2018) believes that the method of political economy is an important part of Marxist political economy and the key to the scientific theoretical system. Das Kapital and other economic works of Marx embody the thought method of dialectical materialism and historical materialism, as well as the scientific abstract method. Zhang Xu (2018) believes that historical materialism is the first great discovery of Marx, the philosophical foundation of all Marx's political economy theories, and the guiding ideology throughout the formation of Marx's political economy system and the creation process of capital. The method used by Marx in Das Kapital should and must become the method of constructing the theoretical system of political economy with Chinese characteristics. It can be seen that many domestic scholars hold a positive attitude towards the relationship between Marx's political economy and the dialectical unity of his construction method.

At present, there are misconceptions about the outdated and useless theory of Marxist political economy in the academic world. The reason is that the principles and methods of Marx's political economy are not correctly viewed, and the overall picture of Marx's political economy is not recognized. In fact, Marx's political economy is a "living" theory with great penetrating power, vitality and reality. It can objectively explain the reality of different historical periods and different regions. The driving force and source behind it is Marx's method of constructing political economy must not negate Marx's principle of political economy because the external manifestation of the current capitalist economic operation law has evolved. In other words, Marx's political economy theory has become a "living" political economy because of its construction method, which has a vigorous metabolism function and can adapt to different practical facts with the changes of historical times and regional conditions, in which construction method plays a decisive role. Marx's political economy still contains a huge ideological treasure, which needs to be dug in depth with the characteristics of The Times. To understand Marx's political economy, we must grasp the relationship between "change" and "unchanged", and find out the core of Marx's political economics that does not change with the situation at any time, and the form of expression that changes with the historical environment. This paper holds that this core is mainly the methodology and values of understanding the world, and a set of academic research paradigm of how to propose, analyze and solve problems. Sticking to Marx's political economy is fundamentally about sticking to the methodology and values of Marx's political economy and learning how to put forward, analyze and solve problems. As Engels pointed out, "Marx's whole view of the world is not doctrine but method. 
It offers not ready-made dogmas, but starting points and methods for further research". Lin Gang (2016), according to Marx on "the critique of political economy," the preface in the classic expression of historical materialism thinks that the principle of methodology consists of the following four specifications of Marxist political economics analysis, namely: (1) The production relations and productivity must adapt to explain the development of social and economic system change; (2) Determine the nature of the entire socio-economic system on the basis of ownership of means of production; (3) To understand political and legal systems and moral norms in terms of economic relations; (4) Analyze people's economic behaviors under the overall constraints of the social and economic system formed in history. The above methodology can also be called the methodology of holism. In terms of the relationship between the individual and the society, and between social existence and social consciousness, the society is not a simple sum of individuals, but an organic whole, and social existence determines social consciousness. This is the embodiment of Marx's fundamental methodology for studying the law of the development of human society. This is the embodiment of the basic methodology of Marx's research on the law of human social development, which requires us to inherit and develop in the construction of the political economy of socialism with Chinese characteristics.

\subsection{How to understand Marx's construction method of political economy correctly}

Marx's construction method of political economy is also his new academic paradigm -- historical materialism, namely historical materialism and dialectical materialism. It is the belief, value and analytical technique shared by all Marxist scholars. It is the theoretical basis for the analysis of Marxist scholars' academic research and the world outlook and methodology shared by Marxist scholars. The core principle of its core is summarized by Engels: the main mode of production and exchange in each historical era and the resulting social structure are the foundation on which the political and spiritual history of the era is based, and only from this History can only be explained on the basis of a foundation. Marx said: "What does the history of thought prove in addition to the transformation of spiritual production with the transformation of material production?"This is the fundamental methodology of Marxism in studying the laws governing the development of human society.

On March 14, 1883, Engels's speech in front of Marx's Tomb further summarized and specifically stated this new academic paradigm as: "As Darwin discovered the law of development in the organic world, Marx discovered the law of development of human history. A simple fact that has always been concealed by the plethora of ideologies: people must first eat, drink, live, wear, and then engage in politics, science, art, religion, etc.; therefore, direct material life materials Production, thus a certain stage of economic development of a nation or an era, constitutes the foundation. People's national facilities, legal viewpoints, art and even religious ideas are developed on this basis. Therefore, it must also be based on this foundation. Explain, not the opposite as in the past."Marx provides us with a set of science, system, effective research paradigm, to guide and inspire us should combine different historical era characteristics and the specific situation to inherit and develop, enrich and perfect Marxist political economics, test of political economics in practice, improve the ability to use political economics to solve practical problems, continue to strengthen self hematopoietic function, fundamentally guarantee the Marxist political economics to keep the strong vitality of the situation.

However the key point is how to define and distinguish the status and importance of the methods used by Marx in his study of political economy. Throughout Marx's thought and principle of political economy, we can find that historical materialism and dialectical materialism run through "Das Kapital" and other works. In recent years, the academic circles also basically agree on the prominent position and function of historical materialism and dialectical materialism in the establishment process of Marx's political economy. Qiu Haiping (2018) holds that materialist dialectics and materialist historical view are Marxist world outlook and historical view, as well as the fundamental methodology of Marxist political economy. Zhao Lei (2018) believes that "from concrete to abstract" is the research method of "Capital". "From abstract to concrete" is the narrative method of "Capital". Materialistic dialectics is the basic method of "Capital" and is Marxist. Methodology is the principle and position that stipulates other specific methods, and the source of the methodology of Capital is dialectical materialism.Hu Lei and Zhao Xueqing (2018) believe that the fundamental methods of Marxist political economics are historical materialism and materialist dialectics. The specific methods include scientific abstract law, concrete to abstract research methods and abstraction to concrete narrative methods, logic and A method of consistent history, a combination of analysis and synthesis, and a quantitative analysis method. Wei Xinghua (2018) proposed that the dialectical materialism and historical materialism methodology applied in Capital is a total and fundamental approach. In addition, Marx also talked about other more specific methods, such as "abstract power." "Methods, whether natural science or the study of philosophy and social sciences, need to apply abstract methods. Han Xiping and Wang Xiaohui (2019) believe that the use of materialist dialectics to study political economy is a unique methodological aspect of Marxist political economy. It is necessary to clarify the subject and leading position of materialist dialectics in the study of Chinese Marxist political economy in the 21st century. 
Meng Jie (2019) believes that the narrative method of Capital Theory, from abstraction to concreteness, is the expression and construction principle of the entire Marx economic system. It is not a diachronic method but a synchronic method. A correct understanding of the narrative method of Capital is of great significance for the construction of socialist political economy with Chinese characteristics.

In summary, Marx opened up a new academic paradigm of historical materialism and dialectical materialism, using a combination of "from concrete to abstract", "from abstract to concrete", combination of logic and history, and contradiction analysis. Research methods, as well as narrative methods, both methodological and concrete, have carried out a comprehensive and in-depth anatomy and criticism of the whole process of "production, distribution, exchange, consumption" of classical political economy and capitalist production methods. To gradually restore and reproduce the truth of capitalist production methods, and to construct a scientific and complete political economics method. For this reason, Marx's political economics theory is critical and revolutionary, but Marx's political economic construction method is constructive.

\section{The innovative development of the political economy of socialism with Chinese characteristics is in a historical opportunity period}

Over the past 70 years, China's socialist construction has achieved tremendous development achievements, the country's comprehensive strength and people's living standards have improved remarkably, opening up the development path of socialism with Chinese characteristics and contributing to the "China Program" for global economic development and wealth growth. The socialist practice of China's reform and development promotes the rapid development of China's political economy and provides fresh cases and materials for the development of political economy. But on the whole, the domestic political economy theory research still lags behind the practice, and the theory and the practice are not coordinated. Strictly speaking, the theory of political economy of socialism with Chinese characteristics is incomplete at present. In fact, the existing political economy in China is the logical framework of Marx's anatomy of capitalist relations of production. Many scholars actually use capitalist political economics theory to analyze China's socialist practice, and political economic analysis still stays in the interpretation and commentary on policies, institutions, systems and mechanisms in China's socialist practice and on capitalist politics. In the critique of the economy and social system, the analysis and understanding of the laws and trends of socialist economic development with Chinese characteristics are weak, and the economic forecasting and constructive functions are insufficient.

Moreover, with the rapid development and enhancement of China's economic strength, China has created economic development achievements beyond the imagination of the western world. Past economic theories have been unable to effectively explain China's economic development phenomenon, and we can no longer rely on the principles of western economics to guide the further development of China's economic reform and opening up. On the contrary, it has now entered a new stage of the reverse influence of China's economic development practice road and the promotion of world economic development. This requires a more comprehensive conclusion of the formation of socialist political economy with Chinese characteristics and the promotion of the socialist political economy with Chinese characteristics. China promotes the development of the world economy and provides China's economic theory, showing the responsibility of the big countries.

At the same time, it is very realistic to insist on using Marx's methodology to construct political economy with Chinese characteristics. Since the reform and opening up, the practice of socialist reform with Chinese characteristics has been influenced by Western economics and capitalist political economic theory and values. These theories start from the concept of abstraction, replace the reality with abstract theory, and form new dogmatism and book capitalism. Even some scholars in political economy have lost their self in learning and learning, and have not done it for me. Some scholars have turned the socialist political economy with Chinese characteristics into the bad trend of Western economics or capitalist political economy under the Marxist outer shell. Therefore, in the in-depth promotion of Marx's political economy in China, the construction of socialist political economy with Chinese characteristics, we should take root in China, in the inheritance of innovation and development.

China has a profound foundation and soil for cultivating and developing the political economy of socialism with Chinese characteristics. It needs the political economy theories that were born in, grew up in and originated from the practice of socialism with Chinese characteristics to continuously improve the academic discourse power of political economy of socialism with Chinese characteristics. However, domestic political and economic scholars have not yet established a complete and systematic system of political and economic theories of socialism with Chinese characteristics, and have not realized the application of political and economic theories of socialism with Chinese characteristics to explain, predict and guide the practice of socialism in China. At present, China's development has entered a new stage. 
Driven by Xi Jinping thought on socialism with Chinese characteristics for a new era, the study of political economy of socialism with Chinese characteristics has reached a new climax. How to base on China's national conditions and development practice, reveal new features and new laws, extract and summarize the regular results of China's economic development practice, elevate practical experience into a systematic economic theory, and constantly open up a new realm of Marxist political economy in contemporary China has become an era subject and historical task. Therefore, our country is in the building of theoretical system of socialism with Chinese characteristics political economics major historical opportunity, how to speed up the construction of socialism with Chinese characteristics political economics discipline of academic system and discourse system, promote academic original ability and level, promote academic theory in China, China's development experience to learn physics and chemistry, the internationalization of Chinese economic discourse, the era have entrusted to our contemporary scholars of political economy with a historical task.

\section{The contemporary enlightenment of Marx's political economy construction method}

At present, domestic scholars' research on Marxist Political Economy mainly focuses on Marxist Political Economy theory itself, but the construction method of Marxist Political Economy has not been given due attention, and its intrinsic value has not been fully released. Under the background of the new era, it is of great value and practical significance to use Marx's political economy construction method to construct the political economy of socialism with Chinese characteristics in the new era.

\subsection{Applying Marx's political economy construction method is an inherent requirement}

To construct a theoretical system of political economy with Chinese characteristics must use the Marxist methodology, starting from the history of China's development, and to create economics that is based on Chinese practice and can reflect and lead the laws of world economic development. The path of socialism with Chinese characteristics fully combined with China's actual conditions and is proved by practice great innovation of Marxism, socialism with Chinese characteristics theory origin and Marxist political economics, is the inheritance and innovation of Marxism, and with China's great socialism practice and combined closely with the reform and opening up.

Therefore, the construction of the political economy theory of socialism with Chinese characteristics by using Marx's political economy construction method is in line with dialectical materialism and historical materialism, which is an inherent requirement.

\subsection{Marx's political economy construction method provides a scientific way to correctly understand the socialist mode of production with Chinese characteristics}

Marx's political economy adheres to the historical materialism of the contradictory movement of productivity and production relations. Deng Xiaoping once pointed out, the fundamental task of socialism is to liberate productivity, and develop productivity. Constructing political economics theory system of socialism with Chinese characteristics, we must stick to the Marxist historical materialism and focus on a better construction of socialism with Chinese characteristics, obeying the requirements of the liberation and development of socialist productive forces, the full release of the basic system of socialism with Chinese characteristics the lifeblood of the liberation and development of socialist productive forces. Domestic scholars also put forward constructive views on this. For example, Wei Xinghua (2017) believes that the principles to be adhered to building the political economy of socialism with Chinese characteristics include: the essence of socialism, namely, to liberate and develop the productive forces, eliminate exploitation, eliminate polarization, and eventually achieve common prosperity; The basic economic system in the primary stage of socialism, that is, the ownership structure with public ownership as the main body and multiple forms of ownership developing together; Implement distribution according to work as the main body, multiple distribution modes coexist; Let the market play a decisive role in the allocation of resources and give better play to the role of the government; The theory of China's economic development entering the new normal. That these principles is to build socialism with Chinese characteristics of the old political economics system background and objective conditions, also need hard, careful meticulous rational logic analysis work, abstracting the general from the development of the specific practice of economic concepts and categories, constructing conform to the terms of the economic law of development of socialism with Chinese characteristics system and academic discourse system.

\subsection{Marx's political economy construction method has opened the train of thought for correctly grasping the research object of political economy of socialism with Chinese characteristics}

To construct the political economy of socialism with Chinese characteristics, it is necessary to define the research object of this discipline. And how to determine, we can first get inspiration from the study of Marx's research on political economics objects and methods. Explaining the object of political economics, Marx said in the preface to the first volume of Capital: "What I want to study in this book is the capitalist mode of production and the production relations and exchange relations that are compatible with it". 
The interpretation of Marx's research objects on political economy, although different scholars understand and express different, essentially focus on the mode of production, production relations and productivity and the relationship between them, basically emphasizes the relationship between production relations and productivity. The dialectical relationship and the organic connection between the two, and can not simply "take this to the other" or "she take this".

By analyzing the origin of Marx's research object of political economy, Marx's exposition on the research object of political economy and its implicit dialectical logic and materialistic methods can open up ideas and horizons for the study of social economics with Chinese characteristics. On the whole, Marx's study of capitalist production methods and their corresponding production relations and exchange relations is to reveal the historical evolution of capitalist production methods and the historical necessity of being replaced by socialism from the perspective of historical development laws. In this process, the relationship between productivity and the contradictory movement of production relations plays an important role. China is not based on the mature capitalist productivity, and it is different from the conditions elaborated by Marx in the study of Capital. From the chronological order, China is the first to establish socialist relations of production. However, according to Marx's method of historical materialism, the process of developing socialist productive forces still needs to be carried out actively. In other words, there is no certain condition, and the influence of production relations on productivity is not inevitable. This is also the inherent logic of the main contradictions in our society. In this regard, Marx once affirmed the comments of others on Marx's words. "Because the entire structure of these organisms is different, their organs are different, and the conditions under which organs function are different, etc., the same phenomenon is different. For example, Marx denies that the law of population is the same everywhere at any time. On the contrary, he asserts that each stage of development has his own laws of population... the level of development of productive forces, the relationship between production and the law governing production relations It is different."Moreover, from the perspective of nature, Marx's political economy is a critical and revolutionary political economy, while socialist political economy with Chinese characteristics is constructive political economy. Therefore, the research object of socialist political economy with Chinese characteristics needs to incorporate the production mode of socialism with Chinese characteristics and the relationship between production relations and productivity into the research object.

\subsection{Marx's Method of Constructing Political Economy provides a basis for thinking about the logical starting point of socialist political economy with Chinese characteristics}

As commodities are the basic element of bearing production relations and wealth, Marx regards commodities as the logical starting point for discussing capitalist production methods. Under the capitalist mode of production, commodities can serve as a common logical beginning and destination for all kinds of economic categories, and effectively fit different economic categories.

At present, domestic scholars still have some controversy about the logical starting point of socialist political economy with Chinese characteristics, and put forward different views and viewpoints from different angles. According to Qiu Haiping (2010), the main methodological defect of Chinese political economy or Chinese socialist political economy is simply copying the "productive forces -- relations of production -- superstructure" paradigm in historical materialism, which leads to the contradiction between theory and reality as well as the contradiction between theory itself. We should combine the external constraints that the world history has imposed on China's social development since modern times with the historical conditions of Chinese society itself, and the "state" will inevitably become the logical starting point of China's political economy. He (2017) also put forward at the same time, the socialism with Chinese characteristics in practice is one of the most important characteristic is that the communist party leadership to the whole country and through the country to develop a variety of ownership economy, market economy and social productivity, therefore, the "nation" included in the theoretical system of socialism with Chinese characteristics political economics and as a logical starting point, the political economy of socialism with Chinese characteristics is a significant innovation in theory. Lin Guangbin (2017) on the basis of analyzing Qiu Haiping believes that the establishment of the state power and the establishment of the state theory of socialism with Chinese characteristics is the first condition of political economics, the narrative logic of socialist political economics should be started from the theory of state, and then according to the production, distribution, exchange and consumption of logical order one by one to unfold. Wang Chaoke (2018) pointed out that Marx chose commodity, the element form of social wealth dominated by capitalism, as the logical starting point. And "surplus products" can be used as the logical starting point of political economy of socialism with Chinese characteristics, because only surplus products are the material basis for realizing the common prosperity of the people. Li ding and Wu Chaoyang (2018) proposed that the theoretical system of political economy of socialism with Chinese characteristics should be constructed by taking capital as the starting point, taking the relationship between capital and labor as the main line, and taking people as the center and promoting the all-round development of people as the central category. 
On the surface, different scholars on the logical starting point of the political economy of socialism with Chinese characteristics have different understanding, but from the point of the general direction, mainstream scholars are based on the socialist road with Chinese characteristics, around the main countries, people's main body, wealth to analyze the logical starting point of the political economy of socialism with Chinese characteristics. In fact, the path of socialism with Chinese characteristics, the main body of the state, the main body of the people and wealth are unified. The path of socialism with Chinese characteristics is the premise, the main body of the state is an important carrier, the main body of the people is the foundation and wealth is the guarantee. In our country to realize the common prosperity of the people, cannot leave the rapid development of socialist productive forces and development of high quality, and rapid development of socialist production and high quality development, cannot leave under the leadership of the communist party of China, the country as a whole as the starting point to promote the economic construction of socialism with Chinese characteristics, constantly meet people's increasing needs of development for a better life. Therefore, to promote socialist economic construction, China must adhere to the leadership of the communist party of China, give full play to the overall strength of the country, with the country as the main body to create social wealth, drive the country's comprehensive strength and people's living standards continue to improve. It also fully embodies Marx's historical materialism and dialectical materialism. Based on this, the logical starting point of political economy of socialism with Chinese characteristics should be the main body of state in China.

\subsection{Constructing a New System of Socialist Political Economy with Chinese Characteristics to Accurately Grasp the Characteristics of the Times}

Theory is the product of history, which has completely different form and content in different times. "The great social transformation in contemporary China is not simply a continuation of the master version of China's history and culture, a simple imitation of the model conceived by Marxist classical writers, a reprint of other countries' socialist practices, or a copy of foreign countries' modernization development. It is impossible to find ready-made textbooks," Xi said. Therefore, we should combine the contemporary environment and basic national conditions with the political economy theory of socialism with Chinese characteristics, adapt Marx's political economy methodology to China, keep pace with The Times, study new situations, answer new questions, and make the application of all principles based on the "historical conditions at that time".

As we all know, Marx studied political economics before and after the mid-19th century, the eve of the second industrial revolution. At that time, Europe, especially the United Kingdom, was undergoing dramatic and profound social changes. The capitalist mode of production was in a stage of rapid development, which was already simple. The factory handicraft production mode has changed to the socialized production mode. The capitalist mode of production has exposed a large number of prominent social contradictions and problems. The capitalists have increasingly exploited the proletariat, the basic rights of the proletariat have not been protected, and the bourgeoisie and the proletariat have been caused. The opposition of the class has intensified. This cruel social reality has led to the emergence of the class consciousness of the proletariat. These provide a socio-economic background, ideological soil and creative inspiration for the creation of Capital.170 years later, the world's politics, economy, science and technology and production methods have undergone profound changes. The former Soviet Union and the socialist countries in Eastern Europe have disintegrated. The new situation and new problems in the economic and social development of capitalist countries have even exceeded Marx's original vision. The welfare state system developed in the competition with socialist countries and the informazation, automation, intelligence and global production mode accompanied by the new scientific and technological revolution are making the economic and social development rules of the society present new characteristics, and it is urgent to create new theories to give answers.

As we all know, the 70 years of socialism with Chinese characteristics have created a Chinese path, a Chinese model and a Chinese miracle that has surpassed all previous economic theories. Therefore, to keep pace with The Times to build socialism with Chinese characteristics political economy must adhere to Marxism, especially to adhere to Marxist historical materialism analysis paradigm, because the Chinese surname "she", the construction of soil and foundation is the great exploration and practice of socialism with Chinese characteristics for 70 years; Must be based on the Chinese communist party in China up from stood up, rich, strong and great practice of the process, to reveal the development rule of human society, the law of socialist construction and communist rule, the "three laws" in China's present characteristics and development path as the main content of the political economy of socialism with Chinese characteristics; We must explain clearly the transformation of China's socialist mode of production, such as industrialization, modernization and marketization, and the path, model and prospect of China formed in the process of constantly liberating and developing the productive forces. We must explain clearly the productive forces and relations of production behind the changes of the principal economic contradictions in Chinese society, and the basic forces, basic structures and basic laws of the interactive movement between the economic foundation and the superstructure. 
At the same time, our country has become the world's second largest economy, in the face of gaming and global competition, the new situation of our country in global affairs and governance plays the role and function gradually increase, this requires us to further enhance the national main body as the main global competition and the national consciousness, focusing on the economic system of socialism with Chinese characteristics advantage, built with international vision and global pattern of the political economy of socialism with Chinese characteristics.

All in all, the political economics of innovation and development of socialism with Chinese characteristics, should use the Chinese are doing as the center, the current situation of the development of the world as the basic background, from the practice of the development of China's socialist new materials, find new problems, especially to the "three laws" in China's present characteristics and development path as a systematic summary of the main part of the socialist practice, and strengthen the analysis and research of developing the socialist market economy, the extract has a rational new theory, Outlines the regularity of new practice. This is the focus of the political economy of building socialism with Chinese characteristics. We must focus on building a foothold in China, learning from foreign countries, excavating history, grasping the contemporary, caring for mankind and facing the future, focusing on building political economy with Chinese characteristics, and fully embodying Chinese characteristics in guiding ideology, disciplinary system, academic system, and discourse system, Chinese style, reflecting inheritance and nationality, originality and time, system and professionalism. We should deepen the theoretical analysis and logical academic construction of the "China model" of economic construction, promote innovative breakthroughs in political economy with Chinese characteristics, enhance socialist road confidence, theoretical self-confidence, institutional self-confidence and cultural self-confidence with Chinese characteristics, and continuously improve China's overall national strength. The global competitiveness and the right to speak in global governance provide theoretical support for the great rejuvenation of the Chinese nation.

\section{References}

Anthology of Mao Zedong.(1999) Beijing: People's Publishing House,8, 138-139.

Selected Works of Marx and Engels.(2012)Beijing: People's Publishing House, 2,52,50,93-94,2,93,93.

Selected Works of Marx and Engels.(2009)Beijing: People's Publishing House, 10, 231,239.

Hu Lei, and Zhao Xueqing.(2018) The fundamental and concrete method of Marxist political economy -commemorating the 200th anniversary of Marx's birth. Economist, 9,12-21.

Han Xiping, and Wang Xiaohui.(2019) The Construction of Chinese Marxist Political Economy in the 21st Century. Governance Modernization Studies, 1,22-27.

Lin Gang.(2016) Adhering to the Fundamental Principle of Marxism is Adhering to Marx's Methodological Principles. Economic Research Journal,3,18-21.

Lin Guangbin.(2017) China's National Theory and Political Economics Theoretical System Innovation. Journal of Graduate School of Chinese Academy of Social Sciences, 11,47-60.

Li Ding, and Wu Chaoyang.(2018) The Construction Method of the Theoretical System of Socialist Political Economy with Chinese Characteristics. On Economic Problems,11,19-25.

Meng Jie. Critical reflection on the principle of consistency between logic and history -- taking several debates on political economy with Chinese characteristics as a reference.(2019)Research on Financial and Economic Issues, $1,13-19$.

Qiu Haiping.(2010) On the innovation and logical starting point of China's political economy -- based on the historical materialism on the applicability of China's modern history. Teaching and Research,3,19-24.

Qiu Haiping. (2017) On the Research Object and Theoretical Characteristics of Socialist Political Economy with Chinese Characteristics_Comment on Zhang Yu's Political Economy of Socialism with Chinese Characteristics. Teaching and Research,3,5-11.

Qiu Haiping.(2018) Das Kapital and the methods and methodology of socialist political economy with Chinese characteristics. Journal of south China normal university,6,43-50.

Wei Xinghua.(2017) On the Research Object of Political Economy of Socialism with Chinese Characteristics. Mao Zedong and Deng Xiaoping Theory Research,10,22-25.

Wei Xinghua.(2018) Grasping the research object of Capital in accordance with Marx's system description. Economic Perspectives, 10,21-26.

Wang Chaoke.(2018) The Logical Starting Point of Political Economy of Socialism with Chinese Characteristics. The Ideological Front,2,75-83.

Xi Jinping.(2017) The Governance of China. Foreign Languages Press,2,344. 
Zhang Xu.(2018) The establishment of the research object and method of Marxist political economy. Economic Review, 5,29-37.

Zhang Xiong.(2015) Critique of Political Economy: Pursuing the "Political and Philosophical Realization" of the Economy. Social Sciences in China,1,4-22.

Zhao Lei.(2018) The methodological implication of "I am not a Marxist" -- based on the methodology of Das Kapital. China Review of Political Economy,6,140-157. 